\title{
THE DYNAMICS OF PHOTOSYNTHETIC PIGMENTS IN WINTER WHEAT LEAVES WHEN USING NITROGEN FERTILISERS
}

\author{
Aistė JUCHNEVIČIENĖ, Institute of Agricultural and Food Science, Aleksandras Stulginskis University, Studentų g. 11, \\ Akademija LT-53361, Kauno raj., Lithuania. aiste.zuzaviciute@inbox.lt (corresponding author) \\ Ilona VAGUSEVIČIENĖ, Institute of Agricultural and Food Science, Aleksandras Stulginskis University, Studentų g. 11, \\ Akademija LT-53361, Kauno raj., Lithuania. i.vaguseviciene@gmail.com
}

\begin{abstract}
The paper investigates the effect of nitrogen fertilisers on the amount of photosynthetic pigments in winter wheat leaves. The research was carried out in the period between 2012 and 2013 at the Experimental Station of Aleksandras Stulginskis University in carbonate shallow gleyic leached soil, (Calc(ar)i-Epihypogleyic Luvisol). The object of investigation: winter wheat cultivars 'Zentos' and 'Ada'. Granular superphosphate $\left(\mathrm{P}_{60}\right)$ and potassium chloride $\left(\mathrm{K}_{60}\right)$ fertilisers were spread during sowing, while amonium nitrate $\left(\mathrm{N}_{60}\right)$ was used in tillering time (BBCH 23-25), after the vegetative growth had resumed. Additionally, the plants were treated with foliar fertiliser urea solution: $\mathrm{N}_{30}, \mathrm{~N}_{40}$ at booting stage (BBCH 34-36) and $\mathrm{N}_{15}, \mathrm{~N}_{30}$ at milk ripening stage (BBCH 71-74).

After the analysis of the data, it was established that additional fertilization with $\mathrm{N}_{30}$ and $\mathrm{N}_{40}$ fertiliser application rates at later stages of plant development stimulated the accumulation of photosynthetic pigments and prolonged the period of active photosynthesis. Irrespective of treatment with nitrogen fertilisers, genetic properties of the cultivar also had influence on the accumulation of the pigments. Wheat cultivar 'Zentos' tended to accumulate larger amounts of pigments. The highest amounts of pigments were found at the beginning of milk ripening stage before additional treatment with $\mathrm{N}_{15}, \mathrm{~N}_{30}$ fertiliser application rates.
\end{abstract}

Keywords: nitrogen fertilizer, photosynthetic pigments, winter wheat.

\section{INTRODUCTION}

Photosynthesis is one of the fundamental physiological processes determining the productivity of plants. Only optimal amount and ratio of photosynthetic pigments ensure effective functioning of the photosynthetic apparatus (Scebba et al., 2003; Šabajevienė et al., 2006; Sakalauskienè et al., 2008; 2009). To have normal photosynthesis activity, the ratio of chlorophylls $a$ and $b$ in the leaves of plants of the family Poaceae should not be lower than 3:1 (Bluzmanas et al., 1991; Šlapakauskas ir Duchovskis, 2008).

The amount of pigments in plants depends on a number of factors: genetic properties of a cultivar (Sasnauskas et al., 2009), the growth and development stage, environmental conditions (Bojovic and Stojanovic, 2005, Duchovskis et al., 2006; Sakalauskienè et al., 2013) as well as crop density (Balčiūnas et al., 2008; Samborski et al., 2009). The warming of the climate is changing moisture and temperature regimes that have significant impact on the process of photosynthesis and plant chlorophyll content (Guo et al., 2006; Kim et al., 2007; Guo et al., 2008; Sirtautas et al., 2011). Chlorophyll is extremely sensitive to changes in nitrogen content in soil as a large part of the nitrogen is in the composition of the pigments (Kopsell et al., 2004). A number of researches have been done in which amounts of chlorophylls were measured and the photosynthesis process was established to optimise fertilisation technologies (Bojovic and Stojanovic, 2005; Cartelat et al., 2005; Spaner et al., 2005; Kichey et al., 2006; Fritchi and Ray, 2007; Houles et al., 2007; Leliūnienė et al., 2013; Vagusevičienè et al., 2013; Juchnevičienè et al., 2015).

Fertilization with nitrogen fertilizers stimulates the operation of the photosynthetic apparatus, maintains adequate chlorophyll $a$ and $b$ ratio in plants, intensifies growth and slows down plant development (Kopsell et al., 2004; Tranavičienė et al., 2007; Šlapakauskas ir Duchovskis, 2008). The highest chlorophyll content is accumulated at the beginning of flowering, therefore it is stated that chlorophyll is also involved in morphogenetic processes (Samuolienè et al., 2007; Šlapakauskas ir Duchovskis, 2008; Samuoliene ir Duchovskis, 2012). From the end of seedling growth, when the aging process begins, the system of chlorophylls is no longer a suitable nitrogen nutrition indicator (Li et al., 2006; Wingler et al., 2006).

Depending on the environmental conditions, an appropriately selected fertilizing scheme postpones the degradation of photosynthetic pigments, and extends the period of active photosynthesis as well as ensures efficient transport of assimilates to the seeds, thus determining the yield (Tranavičienè, 2009). Productivity can be raised by controlling and improving growth conditions in this way optimising photosynthesis (Sharma-Natu, Ghildiyal, 2005).

Copyright (C) 2015 The Authors. Published by Aleksandras Stulginskis University. This is an open-access article distributed under the terms of the Creative Commons Attribution License (CC-BY 4.0), which permits unrestricted use, distribution, and reproduction in any medium, provided the original author and source are credited. 
The aim of the work is to investigate into the effect of nitrogen fertilisers on the amount of photosynthetic pigments in winter wheat leaves.

\section{MATERIALS AND METHODS}

The investigation was conducted during the period between 2012 and 2013 at the Experimental Station of Aleksandras Stulginskis University. The cultivars of winter wheat under investigation: 'Zentos' (Germany) and 'Ada' (Lithuania).

The soil: carbonate shallow gleyic leached soil, (IDg8-k) Calc(ar)i-Epihypogleyic Luvisol (LVg-p-w-cc). The plough layer: weakly alkaline $\left(\mathrm{pH}_{\mathrm{KCl}}\right.$ 7.2), with medium humus content (2.48\%), high content of phosphorus (271.0 $\left.\mathrm{mg} \mathrm{kg}^{-1} \mathrm{P}_{2} \mathrm{O}_{5}\right)$ and potassium $\left(184.0 \mathrm{mg} \mathrm{kg}^{-1} \mathrm{~K}_{2} \mathrm{O}\right)$. The field experiment was carried out in five variants with four replications. Total plot size was $40 \mathrm{~m}^{2}$ (4x10) and harvested plot size was $20 \mathrm{~m}^{2}(2 \mathrm{x} 10)$. The plots were arranged in random order.

Winter rape was used as a preceding crop of winter wheat. Major work to set up the experiment consisted of autumn ploughing ( $25 \mathrm{~cm}$ in depth), cultivation, harrowing, sowing and the application of phosphorus and potassium fertilizers $\left(\mathrm{P}_{60} \mathrm{~K}_{60}\right)$. The seeding rate was 4.5 million fertile seeds per ha ${ }^{-1}$.

In sowing time the wheat was fertilised with granular superphosphate $\left(\mathrm{P}_{60}\right)$ (composition: $\mathrm{P}_{2} \mathrm{O}_{5} 20 \%, \mathrm{CaO} 25 \%$, $\mathrm{S} 13 \%$ ) and potassium chloride $\left(\mathrm{K}_{60}\right)$ (composition: $\mathrm{K}_{2} \mathrm{O}_{5} 60 \%$ ), and in spring, after the vegetative growth had resumed, during the tillering time $(\mathrm{BBCH} 23-25)$ the plants were treated with ammonium nitrate $\left(\mathrm{N}_{60}\right)$ (composition: $\mathrm{N}-\mathrm{NH}_{3} 17 \%$, $\mathrm{N}_{-} \mathrm{NO}_{3} 17 \%$ ). Additionally, foliar fertiliser urea (composition: $\mathrm{N}-\mathrm{NH}_{2} 46 \%$;) solution was applied: $\mathrm{N}_{15}, \mathrm{~N}_{30}$ at booting (BBCH 34-36) and $\mathrm{N}_{30}, \mathrm{~N}_{40}$ at milk ripening (BBCH 71-74) stages.

The scheme of the experiment:

1. Control $-\left(\mathrm{P}_{60} \mathrm{~K}_{60}\right)$ in sowing time $+\mathrm{N}_{60}$ in tillering time (Background).

2. Background $+\mathrm{N}_{30}$ at booting stage $+\mathrm{N}_{15}$ in milk ripening stage.

3. Background $+\mathrm{N}_{30}$ at booting stage $+\mathrm{N}_{30}$ in milk ripening stage.

4. Background $+\mathrm{N}_{40}$ at booting stage $+\mathrm{N}_{15}$ in milk ripening stage.

5. Background $+\mathrm{N}_{40}$ at booting stage $+\mathrm{N}_{30}$ in milk ripening stage.

At the end of seedling stage - the beginning of tillering time (BBCH 19-20) the crop was sprayed with herbicide Arrat $0.2 \mathrm{~kg} \mathrm{ha}^{-1}$. Growth regulator Stabilan $1.01 \mathrm{ha}^{-1}$ was used at the beginning of booting stage (BBCH 32), fungicide Allegro Super $0.751 \mathrm{ha}^{-1}+$ growth regulator Medax Top $0.751 \mathrm{ha}^{-1}$ were applied at the end of booting stage (BBCH 37) and fungicide Prosaro® ${ }^{\circledR} 50$ EC $1.01 \mathrm{ha}^{-1}$ was used in the middle of flowering (BBCH 65).

The meteorological conditions of the experiment are described according to the data registered by Kaunas Meteorological Station. September of 2012 was predominantly warm and humid. The average temperature of the month reached $13{ }^{\circ} \mathrm{C}\left(0.8^{\circ} \mathrm{C}\right.$ higher than the multi annual average $)$. The monthly precipitation exceeded the multi annual average by $13.2 \mathrm{~mm}$ (Figure 1$)$.

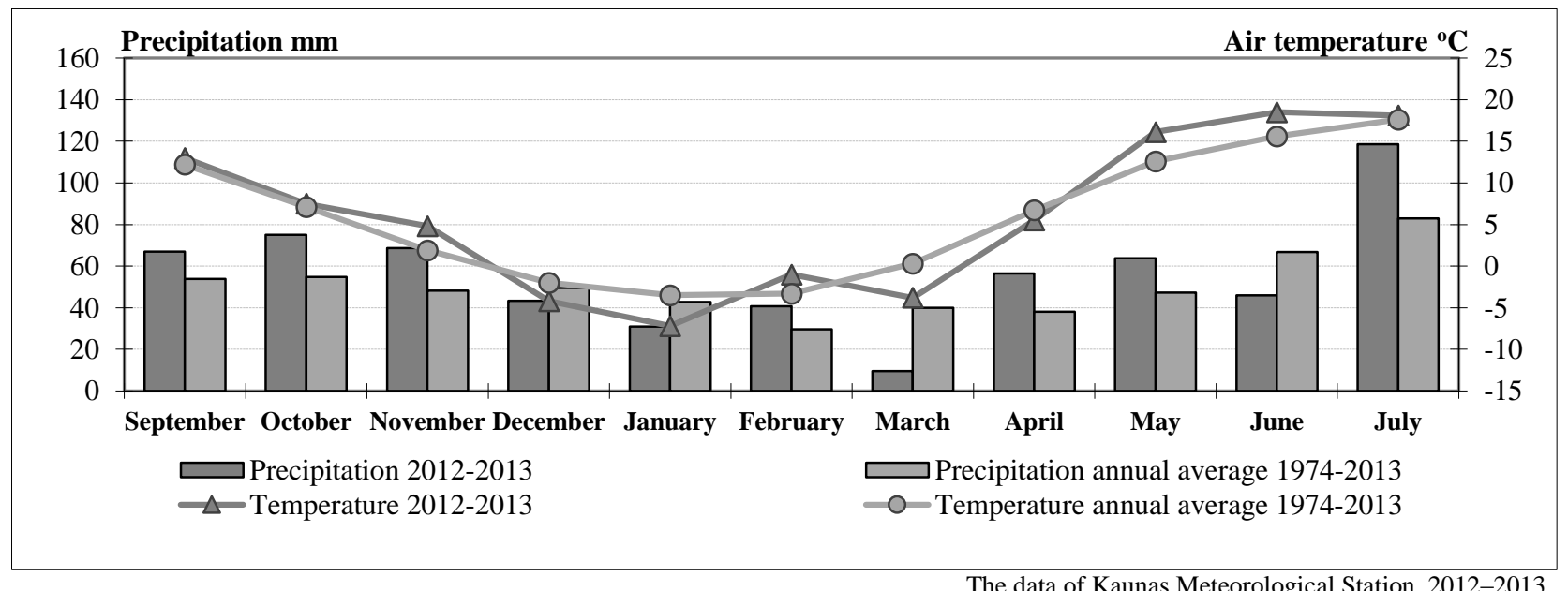

Figure 1. Meteorological conditions during the vegetative period of winter wheat

The winter crops sprouted well and evenly, took root, and their vegetation period lasted until the middle of November. The crop wintered well, although the winter was not warm. The vegetation resumed in the middle of April. The average temperature in the month was $5.5^{\circ} \mathrm{C}\left(1.2^{\circ} \mathrm{C}\right.$ lower than the multi annual average $)$, and the precipitation during the month was $56.5 \mathrm{~mm}$. May was warm and humid enough $(\mathrm{HTC}-1.28)$. The average temperature reached $16.1^{\circ} \mathrm{C}\left(3.5^{\circ} \mathrm{C}\right.$ higher than the multi annual). The average temperature in June was $18.5^{\circ} \mathrm{C}$. The precipitation was $45.9 \mathrm{~mm}(\mathrm{HTC}-0.83) .23 .9^{\circ} \mathrm{C}$ was the highest temperature in the month. The weather in July was changeable. In the first decade of the month there was only $1.5 \mathrm{~mm}$ of rainfall, and the average temperature was $19.1^{\circ} \mathrm{C}$. The second decade was marked by heavy rain $(79.8 \mathrm{~mm})$, and the average temperature was $17.6^{\circ} \mathrm{C}$. The precipitation during the third decade reached $37.2 \mathrm{~mm}$, and the average temperature again reached $19.1^{\circ} \mathrm{C}$.

The agro-chemical analyses of the soil have been performed according to the following methods: $\mathrm{pH}_{\mathrm{KCl}}$ - potentiometric, in $1 \mathrm{~N} \mathrm{KCl}$ extract (LST ISO 10390:2005); organic carbon (C), \% - Tyurin method (ISO 10694:1995); humus, \% - calculated by multiplying the amount of carbon by a factor of 1.724 ; mobile phosphorus $\left(\mathrm{P}_{2} 0_{5}\right)$ and potassium $\left(\mathrm{K}_{2} \mathrm{O}\right), \mathrm{mg} \mathrm{kg}^{-1}-$ Egner-Riehm-Domingo (A-L) method (GOST 26208-84). 
The stages of plant development are presented according to BBCH scale (Meier, 1997).

The amount of photosynthetic pigments (chlorophyll $a, b$ and carotenoids) in green leaf substance was established in $100 \%$ acetone extract spectrophotometrically according to D. Wettstein's method, using a spectrophotometer 'Genesys 6' ('ThermoSpectronic', USA) (Gavrilenko and Zhygalova, 2003).

Photosynthetic indicators were established at different stages of wheat development before and after each application of nitrogen fertilizer.

The data has been assessed according to correlation and regression methods using computer program STATISTIKA 7 (Hill and Levicki, 2005). The tables show averages and standard deviations calculated according to the methods recommended for biometric analyses (Sokal and Rohlf, 2000).

\section{RESULTS AND DISCUSSION}

According to the course of the photosynthesis process, the plant's reaction to environmental conditions and the agro-technical means employed can be evaluated (Duchovskis et al., 2015). In order to establish the effect of nitrogen fertiliser on winter wheat, the factors - photosynthetic pigments (chlorophylls $a, b$ and carotenoids) as well as their changes during vegetation - determining the operation of photosynthesis and its productivity were assessed.

The data of the investigation has shown that winter wheat cultivar 'Zentos' tends to accumulate higher amounts of photosynthetic pigments than cultivar 'Ada'. In tillering time (BBCH 23), before the main fertilization with $\mathrm{N}_{60}$ application rate, the largest amount of chlorophyll $a$ was found in wheat cultivar 'Zentos' $\left(1.30 \mathrm{mg} \mathrm{g}^{-1}\right)$ leaves, and slightly lower in the leaves of cultivar 'Ada' $\left(1.26 \mathrm{mg} \mathrm{g}^{-1}\right)$. The differences in the amounts of chlorophyll $b$ and carotenoids in the leaves of both cultivars are negligible. The ratio of chlorophylls $a / b$ in 'Zentos' and 'Ada' wheat before fertilization with $\mathrm{N}_{60}$ application rate was similar (2.64 and 2.66). The ratio of chlorophylls $a$ and $b$ being lower than 3 demonstrates that unfavourable factors of wintering act as stressors. After the main fertilization, the same trend as that before fertilisation was noticed. Cultivar 'Zentos' (chlorophyll $a-1.35 \mathrm{mg} \mathrm{g}^{-1}$, chlorophyll $b-0.48 \mathrm{mg} \mathrm{g}^{-1}$ ) tends to accumulate more photosynthetic pigments than 'Ada' (chlorophyll $a-1.33 \mathrm{mg} \mathrm{g}^{-1}$, chlorophyll $b-0.46 \mathrm{mg} \mathrm{g}^{-1}$ ). Before and after fertilization with $\mathrm{N}_{60}$ application rate, when comparing the amounts of chlorophylls $a, b$ and carotenoids, we can see that they changed only slightly. The ratio of chlorophylls $a / b$ in wheat cultivars 'Zentos' and 'Ada' leaves increased after fertilization (Tables 1,2).

Table 1. The amount of photosynthetic pigments in winter wheat leaves, $2013(\mathrm{n}=4)$

\begin{tabular}{|c|c|c|c|}
\hline Stages of plant development & Nitrogen fertilizer application rates & 'Zentos' & 'Ada' \\
\hline \multicolumn{4}{|c|}{ The amount of chlorophyll $a, \mathrm{mg} \mathrm{g}^{-1}$} \\
\hline BBCH 23 & $\mathrm{~N}_{0}$ & $1.30 \pm 0.111$ & $1.26 \pm 0.056$ \\
\hline BBCH 25 & $\mathrm{~N}_{60}$ & $1.35 \pm 0.074$ & $1.33 \pm 0.106$ \\
\hline BBCH 34 & $\mathrm{~N}_{60}$ & $1.36 \pm 0.166$ & $1.66 \pm 0.082$ \\
\hline \multirow{3}{*}{ BBCH 36} & $\mathrm{~N}_{60}$ & $1.67 \pm 0.070$ & $1.53 \pm 0.030$ \\
\hline & $\mathrm{N}_{60}+\mathrm{N}_{30}$ & $1.69 \pm 0.111$ & $1.61 \pm 0.114$ \\
\hline & $\mathrm{N}_{60}+\mathrm{N}_{40}$ & $1.62 \pm 0.037$ & $1.50 \pm 0.161$ \\
\hline \multirow{5}{*}{ BBCH 71} & $\mathrm{~N}_{60}$ & $1.99 \pm 0.356$ & $1.68 \pm 0.243$ \\
\hline & $\mathrm{N}_{60}+\mathrm{N}_{30}$ & $1.83 \pm 0.246$ & $1.75 \pm 0.155$ \\
\hline & $\mathrm{N}_{60}+\mathrm{N}_{30}$ & $1.95 \pm 0.288$ & $1.85 \pm 0.518$ \\
\hline & $\mathrm{N}_{60}+\mathrm{N}_{40}$ & $1.96 \pm 0.218$ & $1.91 \pm 0.198$ \\
\hline & $\mathrm{N}_{60}+\mathrm{N}_{40}$ & $1.85 \pm 0.221$ & $1.71 \pm 0.452$ \\
\hline \multirow{5}{*}{ BBCH 74} & $\mathrm{~N}_{60}$ & $1.22 \pm 0.184$ & $1.29 \pm 0.391$ \\
\hline & $\mathrm{N}_{60}+\mathrm{N}_{30}+\mathrm{N}_{15}$ & $1.14 \pm 0.206$ & $1.18 \pm 0.201$ \\
\hline & $\mathrm{N}_{60}+\mathrm{N}_{30}+\mathrm{N}_{30}$ & $1.78 \pm 0.173$ & $1.58 \pm 0.312$ \\
\hline & $\mathrm{N}_{60}+\mathrm{N}_{40}+\mathrm{N}_{15}$ & $1.66 \pm 0.202$ & $1.40 \pm 0.266$ \\
\hline & $\mathrm{N}_{60}+\mathrm{N}_{40}+\mathrm{N}_{30}$ & $1.57 \pm 0.240$ & $1.36 \pm 0.279$ \\
\hline \multicolumn{4}{|c|}{ The amount of chlorophyll $b, \mathrm{mg} \mathrm{g}^{-1}$} \\
\hline BBCH 23 & $\mathrm{~N}_{0}$ & $0.49 \pm 0.031$ & $0.47 \pm 0.030$ \\
\hline BBCH 25 & $\mathrm{~N}_{60}$ & $0.48 \pm 0.022$ & $0.46 \pm 0.043$ \\
\hline BBCH 34 & $\mathrm{~N}_{60}$ & $0.46 \pm 0.044$ & $0.55 \pm 0.076$ \\
\hline \multirow{3}{*}{ ВBCH 36} & $\mathrm{~N}_{60}$ & $0.75 \pm 0.031$ & $0.65 \pm 0.006$ \\
\hline & $\mathrm{N}_{60}+\mathrm{N}_{30}$ & $0.65 \pm 0.036$ & $0.60 \pm 0.038$ \\
\hline & $\mathrm{N}_{60}+\mathrm{N}_{40}$ & $0.61 \pm 0.030$ & $0.58 \pm 0.051$ \\
\hline \multirow{5}{*}{ ВBCH 71} & $\mathrm{~N}_{60}$ & $0.71 \pm 0.144$ & $0.61 \pm 0.089$ \\
\hline & $\mathrm{N}_{60}+\mathrm{N}_{30}$ & $0.67 \pm 0.089$ & $0.63 \pm 0.045$ \\
\hline & $\mathrm{N}_{60}+\mathrm{N}_{30}$ & $0.71 \pm 0.096$ & $0.70 \pm 0.166$ \\
\hline & $\mathrm{N}_{60}+\mathrm{N}_{40}$ & $0.69 \pm 0.089$ & $0.70 \pm 0.075$ \\
\hline & $\mathrm{N}_{60}+\mathrm{N}_{40}$ & $0.68 \pm 0.112$ & $0.62 \pm 0.164$ \\
\hline \multirow{5}{*}{ ВBCH 74} & $\mathrm{~N}_{60}$ & $0.41 \pm 0.043$ & $0.42 \pm 0.144$ \\
\hline & $\mathrm{N}_{60}+\mathrm{N}_{30}+\mathrm{N}_{15}$ & $0.40 \pm 0.056$ & $0.42 \pm 0.071$ \\
\hline & $\mathrm{N}_{60}+\mathrm{N}_{30}+\mathrm{N}_{30}$ & $0.60 \pm 0.075$ & $0.58 \pm 0.089$ \\
\hline & $\mathrm{N}_{60}+\mathrm{N}_{40}+\mathrm{N}_{15}$ & $0.55 \pm 0.078$ & $0.48 \pm 0.096$ \\
\hline & $\mathrm{N}_{60}+\mathrm{N}_{40}+\mathrm{N}_{30}$ & $0.48 \pm 0.081$ & $0.49 \pm 0.077$ \\
\hline
\end{tabular}




\begin{tabular}{|c|c|c|c|}
\hline Stages of plant development & Nitrogen fertilizer application rates & 'Zentos' & 'Ada' \\
\hline \multicolumn{4}{|c|}{ The amount of carotenoids, $\mathrm{mg} \mathrm{g}^{-1}$} \\
\hline BBCH 23 & $\mathrm{~N}_{0}$ & $0.49 \pm 0.065$ & $0.53 \pm 0.011$ \\
\hline BBCH 25 & $\mathrm{~N}_{60}$ & $0.51 \pm 0.042$ & $0.55 \pm 0.039$ \\
\hline BBCH 34 & $\mathrm{~N}_{60}$ & $0.63 \pm 0.089$ & $0.78 \pm 0.052$ \\
\hline \multirow{3}{*}{ ВBCH 36} & $\mathrm{~N}_{60}$ & $0.50 \pm 0.027$ & $0.51 \pm 0.016$ \\
\hline & $\mathrm{N}_{60}+\mathrm{N}_{30}$ & $0.54 \pm 0.031$ & $0.55 \pm 0.032$ \\
\hline & $\mathrm{N}_{60}+\mathrm{N}_{40}$ & $0.52 \pm 0.013$ & $0.51 \pm 0.055$ \\
\hline \multirow{5}{*}{ ВBCH 71} & $\mathrm{~N}_{60}$ & $0.69 \pm 0.093$ & $0.68 \pm 0.061$ \\
\hline & $\mathrm{N}_{60}+\mathrm{N}_{30}$ & $0.65 \pm 0.060$ & $0.62 \pm 0.060$ \\
\hline & $\mathrm{N}_{60}+\mathrm{N}_{30}$ & $0.67 \pm 0.098$ & $0.65 \pm 0.162$ \\
\hline & $\mathrm{N}_{60}+\mathrm{N}_{40}$ & $0.67 \pm 0.057$ & $0.68 \pm 0.068$ \\
\hline & $\mathrm{N}_{60}+\mathrm{N}_{40}$ & $0.67 \pm 0.067$ & $0.62 \pm 0.135$ \\
\hline \multirow{5}{*}{ ВBCH 74} & $\mathrm{~N}_{60}$ & $0.56 \pm 0.059$ & $0.57 \pm 0.141$ \\
\hline & $\mathrm{N}_{60}+\mathrm{N}_{30}+\mathrm{N}_{15}$ & $0.52 \pm 0.075$ & $0.52 \pm 0.050$ \\
\hline & $\mathrm{N}_{60}+\mathrm{N}_{30}+\mathrm{N}_{30}$ & $0.67 \pm 0.049$ & $0.62 \pm 0.090$ \\
\hline & $\mathrm{N}_{60}+\mathrm{N}_{40}+\mathrm{N}_{15}$ & $0.66 \pm 0.061$ & $0.59 \pm 0.110$ \\
\hline & $\mathrm{N}_{60}+\mathrm{N}_{40}+\mathrm{N}_{30}$ & $0.64 \pm 0.096$ & $0.60 \pm 0.060$ \\
\hline
\end{tabular}

At booting stage (BBCH 34) before additional fertilization with $\mathrm{N}_{30}$ and $\mathrm{N}_{40}$ application rates the wheat had begun to build up photosynthetic pigments more intensively. Cultivar 'Ada' (chlorophyll $a-1.66 \mathrm{mg} \mathrm{g}^{-1}$, chlorophyll $b-0.55 \mathrm{mg} \mathrm{g}^{-1}$, carotenoids $-0.78 \mathrm{mg} \mathrm{g}^{-1}$ ) accumulated a considerably larger content of chlorophylls $a, b$ and carotenoids than cultivar 'Zentos' (chlorophyll $a-1.36 \mathrm{mg} \mathrm{g}^{-1}$, chlorophyll $b-0.46 \mathrm{mg}^{-1}$, carotenoids $-0.63 \mathrm{mg} \mathrm{g}^{-1}$ ). At booting stage (BBCH 36) unfertilized and additionally fertilized with $\mathrm{N}_{30}, \mathrm{~N}_{40}$ application rates 'Zentos' wheat amassed larger amounts of pigments, as compared to the other wheat cultivar. 'Zentos' wheat in control plots and in the plots treated with $\mathrm{N}_{30}$ and $\mathrm{N}_{40}$ application rates accumulated $1.62-1.69 \mathrm{mg} \mathrm{g}^{-1}$ of chlorophyll $a$, $0.61-$ $0.75 \mathrm{mg} \mathrm{g}^{-1}$ of chlorophyll $b$ and $0.50-0.54 \mathrm{mg} \mathrm{g}^{-1}$ of carotenoids. Whereas 'Ada' wheat built up $1.50-1.61 \mathrm{mg} \mathrm{g}^{-1} \mathrm{of}^{-}$ chlorophyll $a, 0.58-0.65 \mathrm{mg} \mathrm{g}^{-1}$ of chlorophyll $b$ and $0.51-0.55 \mathrm{mg} \mathrm{g}^{-1}$ of carotenoids. Additional fertilization at booting stage was beneficial to slowing down the degradation of pigments and to keep a longer period of the operation of active photosynthesis system during seed maturation.

At milk ripening stage (BBCH 71) before additional fertilization with $\mathrm{N}_{15}$ and $\mathrm{N}_{30}$ application rates cultivar 'Zentos' accumulated more photosynthetic pigments (Table 2). The photosynthesis system was still functioning intensively at this stage. Depending on fertilizer application rates, the ratio of chlorophylls $a / b$ in 'Zentos' leaves changed from 2.74 to 2.85 and that in cultivar 'Ada' leaves from 2.63 to 2.78. At milk ripening stage (BBCH 74) after additional fertilization with $\mathrm{N}_{15}, \mathrm{~N}_{30}$ the amount of pigments had started to decrease, and the photosynthesis system had begun to function weaker. Depending on fertilizer application rates, the ratio of chlorophylls $a / b$ in 'Zentos' leaves changed from 2.86 to 3.31 and that in 'Ada' leaves altered from 2.72 to 3.13. The differences in the amounts of chlorophylls $a, b$ and carotenoids as well as in the ratio of chlorophylls $a / b$ in the plants of both cultivars were little. However, having used higher fertilizer application rates, a larger amount of pigments was found in the leaves of the plants. At milk ripening stage, after additional fertilization, correlative relationships were established between nitrogen fertilizer rates and the amount of photosynthetic pigments. A strong negative relation ('Zentos' $-r=-0,521$, 'Ada' $-r=-0,664, P<0.05$ ) between fertilizer application rates and the accumulated amount of pigments was established in 'Zentos' and 'Ada' wheat.

Table 2. The ratio of chlorophylls $a / b$ in winter wheat leaves, $2013(\mathrm{n}=4)$

\begin{tabular}{|l|l|c|c|}
\hline Stages of plant development & Nitrogen fertilizer application rates & 'Zentos' & 'Ada' \\
\hline BBCH 23 & $\mathrm{N}_{0}$ & $2.64 \pm 0.212$ & $2.66 \pm 0.065$ \\
\hline BBCH 25 & $\mathrm{N}_{60}$ & $2.80 \pm 0.030$ & $2.88 \pm 0.075$ \\
\hline BBCH 34 & $\mathrm{N}_{60}$ & $2.92 \pm 0.194$ & $3.02 \pm 0.240$ \\
\hline \multirow{4}{*}{ BBCH 36 } & $\mathrm{N}_{60}$ & $2.24 \pm 0.137$ & $2.36 \pm 0.049$ \\
\cline { 2 - 4 } & $\mathrm{N}_{60}+\mathrm{N}_{30}$ & $2.60 \pm 0.104$ & $2.68 \pm 0.046$ \\
\cline { 2 - 4 } & $\mathrm{N}_{60}+\mathrm{N}_{40}$ & $2.68 \pm 0.110$ & $2.59 \pm 0.189$ \\
\hline \multirow{5}{*}{ BBCH 71 } & $\mathrm{N}_{60}$ & $2.78 \pm 0.122$ & $2.74 \pm 0.114$ \\
\cline { 2 - 4 } & $\mathrm{N}_{60}+\mathrm{N}_{30}$ & $2.76 \pm 0.097$ & $2.76 \pm 0.118$ \\
\cline { 2 - 4 } & $\mathrm{N}_{60}+\mathrm{N}_{30}$ & $2.74 \pm 0.117$ & $2.63 \pm 0.137$ \\
\cline { 2 - 4 } & $\mathrm{N}_{60}+\mathrm{N}_{40}$ & $2.85 \pm 0.080$ & $2.72 \pm 0.089$ \\
\cline { 2 - 4 } & $\mathrm{N}_{60}+\mathrm{N}_{40}$ & $2.76 \pm 0.176$ & $2.78 \pm 0.149$ \\
\hline \multirow{5}{*}{ BBCH 74 } & $\mathrm{N}_{60}$ & $2.99 \pm 0.135$ & $2.13 \pm 0.326$ \\
\cline { 2 - 4 } & $\mathrm{N}_{60}+\mathrm{N}_{30}+\mathrm{N}_{15}$ & $2.86 \pm 0.179$ & $2.72 \pm 0.089$ \\
\cline { 2 - 4 } & $\mathrm{N}_{60}+\mathrm{N}_{30}+\mathrm{N}_{30}$ & $3.01 \pm 0.244$ & $2.93 \pm 0.113$ \\
\cline { 2 - 4 } & $\mathrm{N}_{60}+\mathrm{N}_{40}+\mathrm{N}_{15}$ & $3.03 \pm 0.140$ & $2.77 \pm 0.276$ \\
\cline { 2 - 4 } & $\mathrm{N}_{60}+\mathrm{N}_{40}+\mathrm{N}_{30}$ & $3.31 \pm 0.244$ & \\
\hline
\end{tabular}

Nitrogen fertilizer is beneficial to forming the photosynthesis apparatus, retaining the ratio of chlorophylls $a$ and $b$ and ensuring effective photosynthesis, yet the composition of photosynthetic pigments is not sensitive enough an indicator to assess the effect of minor differences in nitrogen application rates (Tranavičienè, 2009). The increase in 
fertilizer application rates had influence on the total amount of photosynthetic pigments (Tranavičienè et al., 2007; Vagusevičienè et al., 2013; Juchnevičienè et al., 2015).

\section{CONCLUSIONS}

Additional fertilization with $\mathrm{N}_{30}, \mathrm{~N}_{40}$ application rates at later stages of winter wheat development slows down the degradation of photosynthetic pigments and prolongs the period of active photosynthesis. Cultivar 'Zentos' accumulates larger amounts of photosynthetic pigments than cultivar 'Ada'. The highest amount of pigments was established at the beginning of milk ripening stage.

\section{REFERENCES}

1. Balčiūnas, M., Jankauskienè, Z., Brazaityte, A., Duchovskis, P. 2008. The effect of plant stand density on flax leaf area index and content of photosynthetic pigments. Zemdirbyste-Agriculture, Vol. 95, No. 4, pp. 97-109.

2. Bluzmanas, P., Borusas, S., Dagys, J. 1991. Augalų fiziologija. Vilnius: Mokslas. 420 p. (In Lithuanian)

3. Bojovic, B., Stojanovic, J. 2005. Chlorophyll and carotenoid content in wheat cultivars as a function of mineral nutrition. Archives of Biological Sciences, Vol. 57, Iss. 4, pp. 283-290. http://dx.doi.org/10.2298/ABS0504283B

4. Cartelat, A., Cerovic, Z. G., Goulas, Y., Meyer, S., Lelarge, C., Prioul, J. L., Barbottin, A., Jeuffroy, M. H., Gate, P., Agati, G., Moya, I. 2005. Optically assessed contents of leaf polyphenolics and chlorophyll as indicators of nitrogen deficiency in wheat (Triticum aestivum L.). Field Crop Research, Vol. 91, Iss. 1, pp. 31-39. http://dx.doi.org/10.1016/j.fcr.2004.05.002

5. Duchovskis, P., Brazaitytè, A., Juknys, R., Januškaitienė, I., Sliesaravičius, A., Ramaškevičienè, A., Burbulis, N., Šikšnianienė, J. B.., Baranauskis, K., Duchovskienè, L., Stanys, V., Bobinas, Č. 2006. Changes of Physiological and Genetic Indices of Lycopersicon Esculentum Mill. by Cadmium under Different Acidicity and Nutrition. Polish Journal of Environmental Studies, Vol. 15, Iss. 2, pp. 235-242.

6. Duchovskis, P., Brazaityte, A., Samuolienè, G., Viršilè, A., Vaštakaitė, V. 2015. Fotofiziologinių tyrimų būklè ir jų taikymo perspektyvos augalininkystėje: studija. Vilnius: LMA, 92 p. (In Lithuanian)

7. Fritchi, F. B., Ray, J. D. 2007. Soybean leaf nitrogen, chlorophyll content, and chlorophyll a/b ratio. Photosynthetica, Vol. 45, pp. 92-98. http://dx.doi.org/10.1007/s11099-007-0014-4

8. Gavrilenko, V. F., Zhygalova, T. V. 2003. Bol 'shoy praktikum po fotosintezu. Moskva. 256 s. (In Russian)

9. Guo, P., Baum, M., Grando, S., Ceccarelli, S. 2006. Evaluation of chlorophyll content and fluorescence parameters as indicators of drought tolerance in barley. Agriculture in Sciences in China, Vol. 5, Iss. 10, pp. 751-757. http://dx.doi.org/10.1016/S1671-2927(06)60120-X

10. Guo, P., Baum, M., Varshney, R. K., Graner, A., Grando, S., Ceccarelli, S. 2008. QTLs for chlorophyll and chlorophyll fluorescence parameters in barley under post-flowering drought. Euphytica, Vol. 162, Iss. 2, pp. 203-214. http://dx.doi.org/10.1007/s10681-007-9629-6

11. Hill, T., Levicki, P. 2005. Statistics methods and applications. Madison, USA, 800 p.

12. Houles, V., Guerfi, M., Mary, B. 2007. Elaboration of a nitrogen nutrition indicator for winter wheat based on leaf area index and chlorophyll content for making nitrogen recommendations. European Journal of Agronomy, Vol. 27, pp. 1-11. http://dx.doi.org/10.1016/j.eja.2006.10.001

13. ISO 10694:1995. Soil quality - Determination of organic and total carbon after dry combustion (elementary anglysis).

14. Juchnevičienè, A., Vagusevičienè, I., Kaminskaite, A., Brazaitytè, A., Duchovskis, P. 2015. The effect of nitrogen fertilisers for the photosynthetic indicators of different cultivars of winter wheat. Žemés ūkio mokslai, Vol. 22, Iss. 1, pp. 15-25.

15. Kichey, T., Heumez, E., Pocholle, P., Pageau, K., Vanacker, H., Dubois, F., Le Gouis, J., Hirel, B. 2006. Combined agronomic and physiological aspects of nitrogen management in wheat highlight a central role for glutamine synthetase. New Phytologist, Vol. 169, pp. 265-278. http://dx.doi.org/10.1111/j.1469-8137.2005.01606.x

16. Kim, S. H., Gitz, D. C., Sicher, R. C., Baker, J. T., Timlin, D. J., Reddy, V. R. 2007. Temperature dependence of growth, development, and photosynthesis in maize under elevated $\mathrm{CO}_{2}$. Environmental and Experimental Botany, Vol. 61, Iss. 3, pp. $224-236$. http://dx.doi.org/10.1016/j.envexpbot.2007.06.005

17. Kopsell, D. A., Kopsell, D. E., Lefsrud, M. G., Curran-Celentano, J., Dukach, L. E. 2004. Variation in lutein, $\beta$-carotene and chlorophyll concentrations among Brassica oleracea cultigens and seasons. Hortscience, Vol. 39, Iss. 2, pp. 361-364.

18. Leliūniené, J., Klimas, E., Samuolienė, G., Duchovskis, P. 2013. The influence of sowing time and fertilization on the assimilative leaf area formation of Festulolium. Rural Development 2013, Proceedings, Vol. 6, Iss. 2, pp. 111-114.

19. Li, L., Yu, Q., Zheng, Y., Wang, J., Fang, Q. 2006. Simulating the response of photosynthate partitioning during vegetative growth in winter wheat to environmental factors. Field Crops Research, Vol. 96, Iss. 1, pp. $133-141$. http://dx.doi.org/10.1016/j.fcr.2005.06.003

20. LST ISO 10390:2005. Dirvožemio kokybè. pH nustatymas (tapatus ISO 10390:1994). Vilnius: Lietuvos standartizacijos departamentas, $2005 \mathrm{~m}$. (In Lithuanianan)

21. Meier, U. 1997. Growth Stages of Mono- and Dicotyledonous Plants. BBCH Monograph. Berlin, Wien: Blackwell Wissenschaftsverlag. $622 \mathrm{p}$.

22. Šabajevienè, G., Kviklys, D., Kviklienė, N. 2006. Rootstock effect on photosynthetic pigment system formation in apple tree leaves. Sodininkystè ir daržininkystè, Vol. 25, No. 4, pp. 79-88.

23. Sakalauskienè, S., Brazaityte, A., Šabajevienè, G., Lazauskas, S., Sakalauskaitè, J., Urbonavičiūtè, A., Samuolienė, G., Duchovskis, P. 2009. Integrated impact of environmental factors on pea (Pisum sativum L.) physiological indicators at organogenesis stages III-IV. Zemdirbyste-Agriculture, Vol. 96, No. 3, pp. 93-101. 
24. Sakalauskienè, S., Šabajevienè, G., Lazauskas, S., Brazaitytė, A., Samuolienė, G., Urbonavičiūtè, A., Sakalauskaitė, J., Ulinskaitė, R., Duchovskis, P. 2008. Integrated impact of water stress and temperature on photosynthetic indices of radish in III-IV organogenesis. Sodininkystè ir daržininkystė, Vol. 27, No. 1, pp. 97-104.

25. Sakalauskienė, S., Sakalauskaitė, J., Lazauskas, S., Povilaitis, V., Auškalnienė, O., Pšibišauskienė, G., Samuolienė, G., Brazaitytė, A., Duchovskis, P. 2013. Interactive effects of elevated $\mathrm{CO}_{2}$, temperature and water stress on Apera spica- venti L. Journal of Food, Agriculture \& Environment, Vol. 11, Iss. 1, pp. 1121-1124.

26. Samborski, S. M., Tremblay, N., Fallon, E. 2009. Strategies to make use of plant sensors-based diagnostic information for nitrogen recommendations. Agronomy Journal, Vol. 101, No. 4, pp. 800-816. http://dx.doi.org/10.2134/agronj2008.0162Rx

27. Samuolienè, G., Duchovskis, P. 2012. Interaction Between Flowering Initiation and Photosynthesis. In: Applied Photosynthesis. InTech. pp. 121-140. http://dx.doi.org/10.5772/26408

28. Samuolienè, G., Šabajevienè, G., Urbonavičiūtè, A., Duchovskis, P. 2007. Carrot flowering initiation: light effect, photosynthetic pigments, carbohydrates. Acta biologija Szegediensis, Vol. 51, Iss. 1, pp. 39-42.

29. Sasnauskas, A., Gelvonauskienè, D., Šikšnianienė, J. B., Šabajevienė, G., Duchovskis, P., Bobinas, Č. 2009. Investigation of biological traits of fifteen apple cultivars. Acta Horticulturae, Vol. 825, pp. 97-102. http://dx.doi.org/10.17660/ActaHortic.2009.825.11

30. Scebba, F., Soldatini, G., Ranieri, A. 2003. Ozone differentially affects and biochemical responses of two clover species: Trifolium repens and Trifolium oratense. Environmental Pollution, Vol. 123, Iss. 2, pp. 209-216. http://dx.doi.org/10.1016/S0269-7491(02)00406-2

31. Sharma-Natu, P., Ghildiyal, M. 2005. Potential targets for improving photosynthesis and crop yield. Current Science, Vol. 88, Iss. 12, pp. 1918-1928.

32. Sirtautas, R., Samuolienė, G., Brazaityte, A., Duchovskis, P. 2011. Temperature and photoperiod effects on photosynthetic indices on radish (Raphanus sativus L.). Zemdirbyste-Agriculture, Vol. 98, No. 1, pp. 57-62.

33. Šlapakauskas, V., Duchovskis, P. 2008. Augalų produktyvumas. Klaipeda: IDP solutions, 253 p. (In Lithuanian)

34. Sokal, R. R., Rohlf, F. J. 2000. Biometry. New York. 887 p.

35. Spaner, D. M., Todd, A. G., Navabi, A., McKenzie, D. B., Goonewardene, L. A. 2005. Can leaf chlorophyll measures at differing growth stages be used as an indicator of winter wheat and spring barley nitrogen requirements in eastern Canada? Journal of Agronomy and Crop Science, Vol. 191, pp. 393-399. http://dx.doi.org/10.1111/j.1439-037X.2005.00175.x

36. Tranavičienè, T. 2009. Azoto poveikis skirtingų paprastojo kviečio (Triticum aestivum L.) veislių fotosintezės ir grūdų kokybės rodikliams: daktaro disertacija. Akademija, 89 p. (In Lithuanian)

37. Tranavičienė, T., Šikšnianienė, J. B., Urbonavičiūtė, A., Vagusevičienė, I., Samuolienė, G., Duchovskis, P., Sliesaravičius, A. 2007. The effect of nitrogen fertilizers on wheat photosynthetic pigment and carbohydrate contents. Biologija, Vol. 53, Iss. 4, pp. 84-88.

38. Vagusevičienė, I., Juchnevičienè, A., Duchovskis, P. 2013. The Effect of Nitrogen Fertilizers on the Changes of Photosynthetic Pigments in Winter Wheat. Rural Development 2013, Proceedings, Vol. 6, Iss. 2, pp. 266-269.

39. Wingler, A., Purdy, S., MacLean, J. A., Pourtau, N. 2006. The role of sugars in integrating environmental signals during the regulation of leaf senescence. Journal of Experimental Botany, Vol. 57, Iss. 2, pp. 391-399. http://dx.doi.org/10.1093/jxb/eri279 